\title{
Progesterone and conceptus elongation in cattle: a direct effect on the embryo or an indirect effect via the endometrium?
}

\author{
M Clemente, J de La Fuente, T Fair ${ }^{1}$, A Al Naib , A Gutierrez-Adan, J F Roche ${ }^{1}$, D Rizos \\ and $\mathrm{P}$ Lonergan ${ }^{1}$
}

Dept de Reproduction Animal, INIA, 28040 Madrid, Spain and ${ }^{1}$ School of Agriculture, Food Science and Veterinary Medicine, University College Dublin, Dublin 4, Ireland

Correspondence should be addressed to P Lonergan; Email: pat.lonergan@ucd.ie

\begin{abstract}
The steroid hormone progesterone $\left(\mathbf{P}_{4}\right)$ plays a key role in the reproductive events associated with pregnancy establishment and maintenance. High concentrations of circulating $P_{4}$ in the immediate post-conception period have been associated with an advancement of conceptus elongation, an associated increase in interferon- $\tau$ production and higher pregnancy rates in cattle. Using in vitro and in vivo models and $\sim \mathbf{8 5 0 0}$ bovine oocytes across six experiments, the aim of this study was to establish the route through which $\mathrm{P}_{4}$ affects bovine embryo development in vitro and in vivo. $m R N A$ for $P_{4}$ receptors was present at all stages of embryo development raising the possibility of a direct effect of $P_{4}$ on the embryo. Exposure to $P_{4}$ in vitro in the absence or presence of oviduct epithelial cells did not affect the proportion of embryos developing to the blastocyst stage, blastocyst cell number or the relative abundance of selected transcripts in the blastocyst. Furthermore, exposure to $\mathrm{P}_{4}$ in vitro did not affect post-hatching elongation of the embryo following transfer to synchronized recipients and recovery on Day 14. By contrast, transfer of in vitro derived blastocysts to a uterine environment previously primed by elevated $\mathrm{P}_{4}$ resulted in a fourfold increase in conceptus length on Day 14 . These data provide clear evidence to support the hypothesis that $P_{4}$-induced changes in the uterine environment are responsible for the advancement in conceptus elongation reported previously in cattle and that, interestingly, the embryo does not need to be present during the period of high $\mathrm{P}_{\mathbf{4}}$ in order to exhibit advanced elongation. Reproduction (2009) 138 507-517
\end{abstract}

\section{Introduction}

The steroid hormone progesterone $\left(\mathrm{P}_{4}\right)$ plays a key role in the reproductive events associated with pregnancy establishment and maintenance. High concentrations of circulating $\mathrm{P}_{4}$ in the immediate post-conception period have been associated with an advancement of conceptus elongation, an associated increase in interferon- $\tau$ production and higher pregnancy rates in cattle (Lamming \& Royal 1999, Mann \& Lamming 2001, Inskeep 2004, Stronge et al. 2005, McNeill et al. 2006) and sheep (Ashworth et al. 1989, Satterfield et al. 2006).

The effects of elevated $\mathrm{P}_{4}$ shortly after conception on the advancement of conceptus elongation have been convincingly demonstrated in cattle and sheep. Garrett et al. (1988) administered $100 \mathrm{mg} \mathrm{P}_{4}$ on Days 1, 2, 3, and 4 of pregnancy which resulted in an increased peripheral plasma $\mathrm{P}_{4}$ concentration on Days 2-5 and significantly larger conceptuses on Day 14. Using a $\mathrm{P}_{4}$ implant on Day 3 of pregnancy, Carter et al. (2008) significantly elevated $\mathrm{P}_{4}$ concentrations until Day 8 and this was associated with a larger conceptus recovered at slaughter on Day 16. Similarly, when ewes received daily injections of $25 \mathrm{mg} \mathrm{P}_{4}$ from $36 \mathrm{~h}$ postmating, blastocyst diameter increased by $220 \%$ on Day 9 and the time of elongation of blastocysts to a filamentous conceptus on Day 12 was advanced (Satterfield et al. 2006); these effects of $\mathrm{P}_{4}$ treatment on blastocyst development were blocked by administration of $\mathrm{RU} 486$, a $\mathrm{P}_{4}$ receptor (PGR) antagonist.

From the above, it is clear that the concentration of circulating $\mathrm{P}_{4}$ has an effect on the developing embryo. This effect is likely as a result of downstream effects of $\mathrm{P}_{4}$-induced changes in gene expression in the tissues of the uterus (Bauersachs et al. 2006, Satterfield et al. 2006, Forde et al. 2009) resulting in changes in the composition of histroph to which the developing embryo is exposed. Whether any of the effects of $\mathrm{P}_{4}$ is directly on the embryo or whether the observed advancement of development is mediated solely through changes induced in the endometrium is, as yet, unknown. In an attempt to answer this question, some authors have added $\mathrm{P}_{4}$ to embryo culture medium in vitro and examined development to the blastocyst stage. Results, however, have been varied and contradictory with some authors reporting positive effects of $\mathrm{P}_{4}$ (Ferguson et al. 2005, Merlo et al. 2007) while others have reported no effect (Reggio et al. 1997, Goff \& Smith 1998). 
These contradictory observations may be partially explained by the culture system used, as steroids are known to be lipophilic and culture under oil, the system used in many laboratories, may result in depletion from the medium (Shimada et al. 2002).

Many of the actions of $\mathrm{P}_{4}$ are mediated through binding to its nuclear receptor (PGR). This classical PGR was originally characterized in the rodent uterus (Milgrom et al. 1970), and then shortly after in humans (Rao et al. 1974). It was subsequently shown to exist in two isoforms, PGRA and PGRB, both of which similarly bind $\mathrm{P}_{4}$ with high affinity (Lessey et al. 1983). Selective knockout experiments in mice have indicated that PGRA is both necessary and sufficient to elicit the $\mathrm{P}_{4}$-dependent reproductive responses necessary for female fertility while PGRB is required to elicit normal proliferative responses of the mammary gland to $\mathrm{P}_{4}$ (Conneely et al. 2002). Two related proteins with progestin binding activity were subsequently described, namely PGR membrane component (PGRMC) 1 and 2 (Falkenstein et al. 1996, Meyer et al. 1996, Gerdes et al. 1998). While only minimal information is available for PGRMC2, PGRMC1 has both high- and low-affinity $\mathrm{P}_{4}$ binding sites (Meyer et al. 1996), has a single transmembrane spanning domain, and attenuates apoptosis in cultured rat (Peluso et al. 2006) and human (Engmann et al. 2006) granulosa cells in response to $\mathrm{P}_{4}$ treatment. Whether these receptors function in bovine embryos is unknown.

Therefore, using $\sim 8500$ bovine oocytes across six experiments, this study was designed to answer the following questions: 1) is there mRNA for the PGR on bovine embryos during early preimplantation development, a time when elevated $\mathrm{P}_{4}$ in vivo is associated with an advancement in post-hatching development? 2) does addition of $\mathrm{P}_{4}$ to the culture medium of bovine embryos under controlled conditions affect blastocyst development in vitro and subsequent embryo survival and elongation in vivo following transfer to synchronized recipient heifers? and 3 ) does elevated $\mathrm{P}_{4}$ in the early days of the estrous cycle prepare the endometrium and uterine environment to advance the elongation of the conceptus following transfer of blastocysts produced in vitro in the absence of $\mathrm{P}_{4}$ ?

\section{Results}

\section{PGR $m R$ NA relative abundance in bovine embryos}

PGR mRNA was detected at all stages of early embryo development except the morula stage (Fig. 1A). The relative abundance of $P G R$ mRNA was highest in immature oocytes and lowest at the 2- to 4-cell and 16 cell stages. Both PGRMC1 and 2 were detected at all stages of development, decreasing from oocyte to embryonic genome activation and increasing at the blastocyst stage (Fig. 1B and C). A small number of mRNA copies of $P G R$ were detected per blastocyst
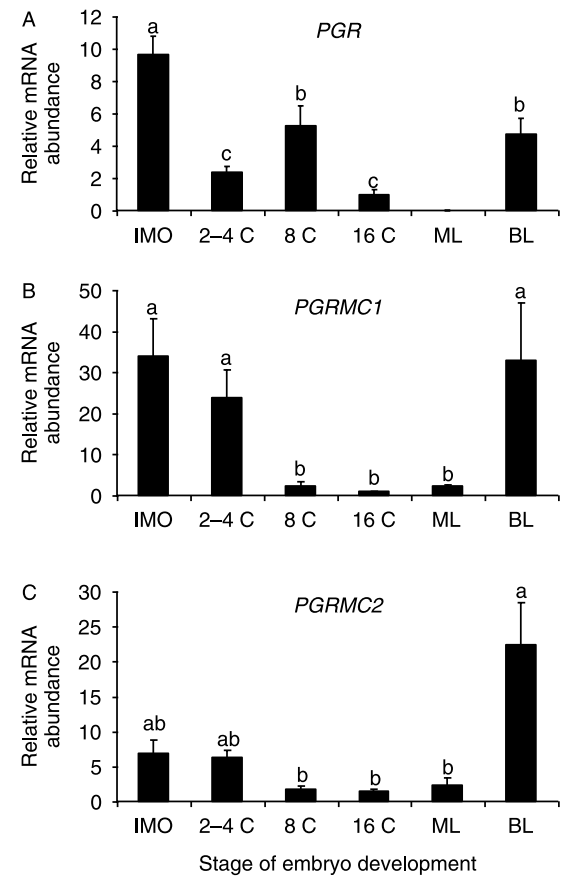

Figure 1 Presence of progesterone receptor mRNA on immature bovine oocytes and preimplantation embryos. RNA was extracted from pools of 10 immature oocytes (IMO), 2- to 4-cell, 8-cell, 16-cell, morula (ML) and blastocyst (BL) stage embryos. (A) Nuclear progesterone receptor $(P G R)$; (B) progesterone receptor membrane component 1 (PGRMC1); and $(\mathrm{C})$ progesterone receptor membrane component 2 (PGRMC2).

(10 \pm 2.7$)$. For PGRMC1, the number of mRNA copies per blastocyst was higher $(10111 \pm 2548)$ while for $P G R M C 2$ the number was intermediate $(1366 \pm 160)$.

\section{$P_{4}$ concentration in the mid-luteal bovine oviduct}

Mean $\mathrm{P}_{4}$ concentration in the oviduct flushings was $4.0 \pm 0.44 \mathrm{ng} / \mathrm{ml}(n=23) . \mathrm{P}_{4}$ was undetectable in the PBS used for flushing. In the stock solution used as a control for the assay, $17.29 \pm 1.02 \mathrm{ng} / \mathrm{ml} \mathrm{P}_{4}$ was detected from the expected $20 \mathrm{ng} / \mathrm{ml}$ concentration.

\section{Disappearance of $\boldsymbol{P}_{\mathbf{4}}$ during culture}

$\mathrm{P}_{4}$ concentration in synthetic oviduct fluid (SOF) on Day 1 (first day of in vitro embryo culture) was as expected $(\sim 35 \mathrm{ng} / \mathrm{ml})$. Culture in $25 \mu \mathrm{l}$ droplets under mineral oil resulted in the rapid depletion of $\mathrm{P}_{4}$ such that by Day 3 it was barely detectable $(0.1-1.6 \mathrm{ng} / \mathrm{ml})$. When culture took place in a larger volume of medium $(500 \mu \mathrm{l})$ in the absence of oil, $\mathrm{P}_{4}$ concentrations remained unchanged $(39-40 \mathrm{ng} / \mathrm{ml})$ throughout the 7 days of culture (Fig. 2A); however, in the presence of embryos the concentration decreased gradually over the subsequent 7 days such that by Day 7 approximately half of the original concentration remained ( $\sim 15 \mathrm{ng} / \mathrm{ml}$; Fig. $2 A)$. Similarly, the presence of a bovine oviduct epithelial cell (BOEC) 

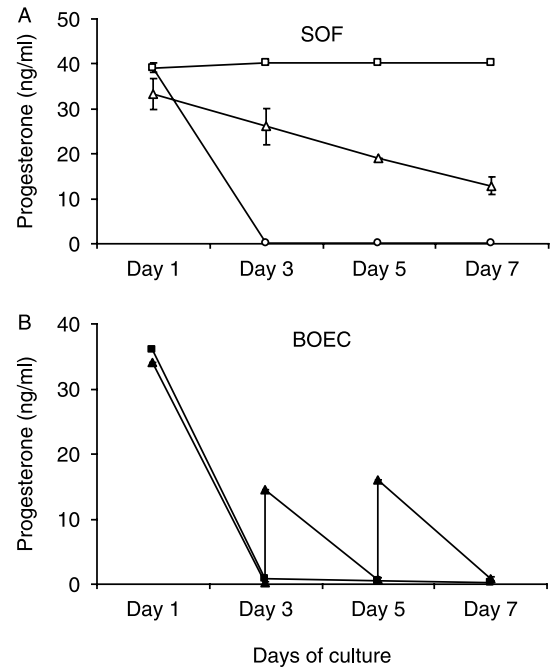

Figure 2 Effect of culture system on the rate of disappearance of progesterone from culture medium in the absence (A) or presence (B) of a bovine oviduct epithelial cell (BOEC) monolayer. Following addition of a known quantity $\left(1 \times 10^{-7} \mathrm{M}\right)$ of progesterone to the culture medium on Day 1, the concentration remaining on Days 3, 5 and 7 of culture was assessed. Culture conditions tested included: i) $25 \mu \mathrm{l}$ droplets of SOF under mineral oil, the system of culture routinely used on our laboratory, open circles; ii) $500 \mu \mathrm{l}$ SOF in wells (without embryos), open squares; iii) $500 \mu \mathrm{l} \mathrm{SOF}$ in wells with embryos, open triangles; iv) $500 \mu \mathrm{l} \mathrm{SOF}$ in co-culture with BOEC (without embryos), closed squares; and v) $500 \mu \mathrm{l} \mathrm{SOF}$ in co-culture with BOEC with replacement of half of the media every 2 days (without embryos), closed triangles. (Experiment 3).

monolayer resulted in the rapid depletion of $\mathrm{P}_{4}$ from the medium (Fig. 2B); when the medium was replenished every 2 days by removing $250 \mu \mathrm{l}$ and replacing it with $250 \mu \mathrm{l}$ medium containing the original concentration of $\mathrm{P}_{4}$, concentrations temporarily increased but rapidly returned to low levels (Fig. 2B). Based on these results, all embryo culture in subsequent experiments took place in $500 \mu \mathrm{l}$ medium without oil overlay.

\section{Effect of $P_{4}$ supplementation on embryo development in vitro}

Ethanol at the concentrations used to prepare the working solutions of $\mathrm{P}_{4}$ had no effect on any of the parameters studied. Addition of exogenous $\mathrm{P}_{4}$ at any of the concentrations tested did not affect cleavage rate or blastocyst development, irrespective of the absence (Table 1) or presence (Table 2) of a BOEC monolayer. Similarly, there was no evidence of any $\mathrm{P}_{4}$-induced difference in the relative transcript abundance of any of the genes studied in either blastocysts or the cultured oviduct cells (Fig. 3). The cell number and allocation (inner cell mass (ICM), trophectoderm (TE)) within Day 7 blastocysts was not affected by culture with $\mathrm{P}_{4}$ (Table 3 ).

\section{Effect of exposure to $P_{4}$ in vitro on blastocyst elongation in vivo following embryo transfer}

Data on the production of embryos in vitro in the absence or presence of progesterone for embryo transfer and on the recovery of embryos after transfer are shown in Table 4. As expected, there was no difference in the $\mathrm{P}_{4}$ profile of the recipient animals which received control or $\mathrm{P}_{4}$-treated embryos (Fig. 4A). The recovery rate of embryos on Day 14 was similar for both groups (control: $50.4 \pm 5.35 \%$ versus $\mathrm{P}_{4}$-treated: $65.0 \pm 6.75 \%$; Table 4). There was large variation in conceptus size on Day 14, even within the same recipient (Fig. 5). Exogenous $\mathrm{P}_{4}$ in culture up to Day 7 had no effect on embryo dimensions on Day 14 (length: control: $3.80 \pm 0.46 \mathrm{~mm}, n=121$ versus $\mathrm{P}_{4}$-treated: $4.46 \pm 0.53 \mathrm{~mm}, n=130$; Fig. $4 \mathrm{~B}$ ).

\section{Effect of elevated $P_{4}$ in vivo prior to embryo transfer on blastocyst elongation}

Data on the production of embryos in vitro for transfer to progesterone-primed recipients and on the recovery of embryos after transfer are shown in Table 5. Insertion of a $\mathrm{P}_{4}$ releasing intravaginal device (PRID) on Day 3 increased $\mathrm{P}_{4}$ concentration four- to fivefold within $24 \mathrm{~h}$ (Fig. 6A). The concentration remained significantly higher than control animals until Day 7 after which time concentrations were no longer different between control and treated heifers. Elevation of $\mathrm{P}_{4}$ prior to embryo transfer on Day 7 resulted in a significant increase in mean conceptus length and area on Day 14 compared to those recovered from control animals (length: control: $4.27 \pm 0.42 \mathrm{~mm}, n=112$ versus $\mathrm{P}_{4}$-treated: $15.4 \pm 1.61 \mathrm{~mm}, n=79, P<0.001$; Fig. $\left.6 \mathrm{~B}\right)$.

Table 1 Effect of supplementation with progesterone $\left(\mathrm{P}_{4}\right)$ during in vitro culture in synthetic oviduct fluid on the cleavage rate and blastocyst yield of bovine embryos in vitro (Experiment 4, 9 replicates).

\begin{tabular}{|c|c|c|c|c|c|}
\hline & \multirow[b]{2}{*}{$N$} & \multirow[b]{2}{*}{$\begin{array}{c}\text { Cleaved, } \boldsymbol{n} \\
(\text { mean } \pm \text { s.Е.M.\% })\end{array}$} & \multicolumn{3}{|c|}{ Blastocyst yield } \\
\hline & & & $\begin{array}{c}\text { Day } 6, n \\
\text { (mean } \pm \text { s.E.M.\%) }\end{array}$ & $\begin{array}{c}\text { Day } 7, n \\
\text { (mean } \pm \text { s.E.M.\%) }\end{array}$ & $\begin{array}{c}\text { Day } 8, n \\
(\text { mean } \pm \text { s.E.M.\%) }\end{array}$ \\
\hline Control & 410 & $315(77.1 \pm 3.1)$ & $58(16.2 \pm 4.2)$ & $121(31.6 \pm 4.7)$ & $138(36.2 \pm 5.6)$ \\
\hline $0.1 \times 10^{-7} \mathrm{MP}_{4}$ & 402 & $323(80.9 \pm 4.3)$ & $66(17.5 \pm 2.4)$ & $118(31.0 \pm 3.2)$ & $147(38.2 \pm 3.4)$ \\
\hline $1 \times 10^{-7} \mathrm{MP}_{4}$ & 408 & $329(81.8 \pm 3.7)$ & $61(16.8 \pm 2.9)$ & $127(33.8 \pm 4.3)$ & $152(40.0 \pm 4.0)$ \\
\hline $10 \times 10^{-7} \mathrm{MP}_{4}$ & 407 & $329(82.1 \pm 2.7)$ & $71(18.8 \pm 1.8)$ & $138(35.3 \pm 3.1)$ & $154(39.36 \pm 3.5)$ \\
\hline Control (ethanol) & 194 & $161(82.9 \pm 2.7)$ & $19(9.5 \pm 4.5)$ & $57(29.1 \pm 5.7)$ & $68(34.9 \pm 4.5)$ \\
\hline
\end{tabular}

$P>0.05$. 
Table 2 Effect of supplementation with progesterone $\left(\mathrm{P}_{4}\right)$ during in vitro culture in synthetic oviduct fluid in the presence of a bovine oviduct epithelial cell monolayer on the cleavage rate and blastocyst yield of bovine embryos in vitro (Experiment 4, 7 replicates).

\begin{tabular}{|c|c|c|c|c|c|}
\hline & \multirow[b]{2}{*}{$N$} & \multirow[b]{2}{*}{$\begin{array}{c}\text { Cleaved, } \boldsymbol{n} \\
(\text { mean } \pm \text { s.E.M.\% } \%)\end{array}$} & \multicolumn{3}{|c|}{ Blastocyst yield } \\
\hline & & & $\begin{array}{c}\text { Day } 7, n \\
(\text { mean } \pm \text { s.E.M.\%) }\end{array}$ & $\begin{array}{c}\text { Day } 8, n \\
(\text { mean } \pm \text { s.E.M.\%) }\end{array}$ & $\begin{array}{c}\text { Day } 9, n \\
\text { (mean } \pm \text { s.E.M.\%) }\end{array}$ \\
\hline Control & 328 & $245(74.3 \pm 2.6)$ & $74(25.6 \pm 4.9)$ & $99(30.2 \pm 5.2)$ & $102(31.2 \pm 4.9)$ \\
\hline $0.1 \times 10^{-7} \mathrm{MP}_{4}$ & 328 & $248(75.1 \pm 3.0)$ & $68(20.6 \pm 1.1)$ & $92(28.1 \pm 1.7)$ & $97(29.6 \pm 1.6)$ \\
\hline $1 \times 10^{-7} \mathrm{MP}_{4}$ & 328 & $259(78.5 \pm 1.9)$ & $89(27.3 \pm 2.0)$ & $108(33.1 \pm 2.0)$ & $109(33.4 \pm 1.8)$ \\
\hline $10 \times 10^{-7} \mathrm{MP}_{4}$ & 328 & $253(76.8 \pm 1.9)$ & $75(22.8 \pm 1.9)$ & $98(29.9 \pm 2.3)$ & $101(30.9 \pm 2.2)$ \\
\hline
\end{tabular}

$P>0.05$.

\section{Discussion}

The main findings of this study are i) mRNA for PGRs exists on the bovine embryo, raising the possibility of a direct effect of $\mathrm{P}_{4}$ on the embryo ii) supplementation with $\mathrm{P}_{4}$ during in vitro embryo culture does not affect the proportion of zygotes reaching the blastocyst stage in vitro, cell number and allocation within the blastocyst, mRNA abundance of selected transcripts or posthatching elongation in vivo, iii) elevation of $\mathrm{P}_{4}$ in vivo prior to embryo transfer leads to a dramatic increase in conceptus length on Day 14. Taken together, these results suggest that the well described association between early elevation of $\mathrm{P}_{4}$ post conception and advanced conceptus length (Garrett et al. 1988, Satterfield et al. 2006, Carter et al. 2008) is not due to a direct effect of $\mathrm{P}_{4}$ on the embryo but rather due to $\mathrm{P}_{4}$-induced changes in the environment in which the embryo is developing. Furthermore, the early embryo does not need to be present in the uterus when $\mathrm{P}_{4}$ concentrations are elevated in order to benefit from their consequences.
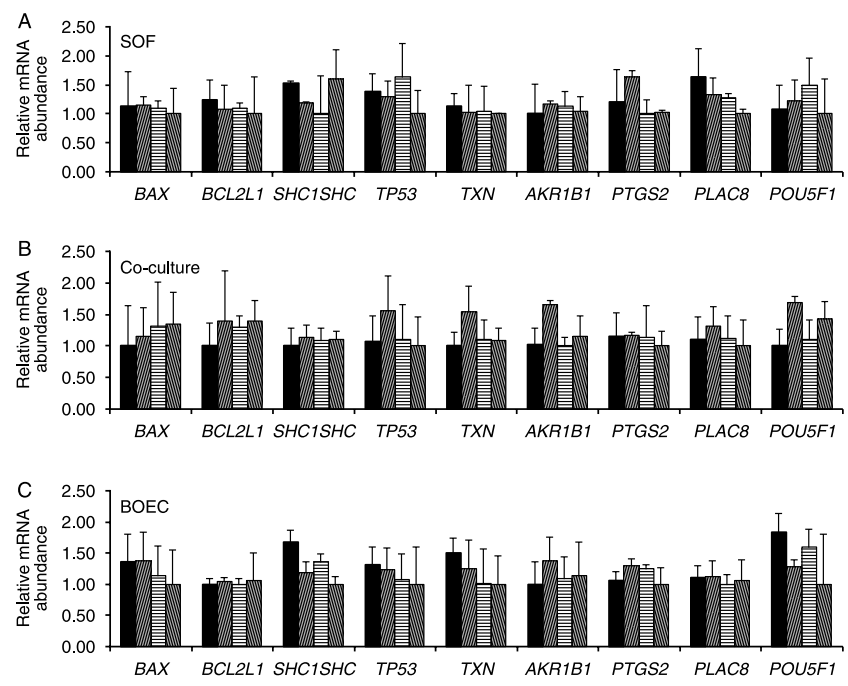

Figure 3 Relative transcript abundance of selected transcripts in bovine blastocysts (A and B) and cultured oviduct cells (C) in the absence (black bars) or presence of increasing concentrations of progesterone. (A) Blastocysts produced in synthetic oviduct fluid (SOF); (B) blastocysts produced in SOF in co-culture with a bovine oviduct epithelial cell (BOEC) monolayer; and (C) BOEC. No differences between progesterone treatment and control $(P>0.05)$.
Several studies have reported lower $\mathrm{P}_{4}$ concentrations in cows that failed to become pregnant although the degree and timing of the association between $\mathrm{P}_{4}$ concentrations and embryo survival are still unclear. For example, some authors have reported a positive association between milk or plasma $\mathrm{P}_{4}$ concentration and embryo survival on Days 4-6 of the estrous cycle (Green et al. 2005, McNeill et al. 2006) while others found no association until Days 14-17 (Chagas e Silva \& Lopes da Costa 2005). Despite these inconsistent results there is an indication that low $\mathrm{P}_{4}$ concentrations during the early post-ovulatory luteal phase, or a delay in the normal rise in $\mathrm{P}_{4}$ at this time are associated with reduced embryo survival (Diskin \& Morris 2008).

Expression of PGRs in embryos has been demonstrated in several species including mouse (Hou \& Gorski 1993), pig (Ying et al. 2000) and horse (Rambags et al. 2008). To our knowledge, the present study shows for the first time $P G R$ mRNA expression in bovine preimplantation embryos. However, the number of transcripts per embryo was low and the functionally is, as yet, unclear. Expression of PGRMC1 has previously been shown in bovine preimplantation embryos (Dode et al. 2006) but, to date, little is known about its function.

Culture of embryos in vitro in droplets of medium necessitates the use of oil to prevent evaporation. The problem of absorption of steroids by the oil overlaying the culture media drops is well known (Shimada et al. 2002, Zheng et al. 2003). One approach to overcome this problem is the pre-equilibration of oil with the appropriate steroid (Zheng et al. 2003). Alternatively, by using a high concentration of $\mathrm{P}_{4}$ at the beginning of incubation (almost $3000 \mathrm{ng} / \mathrm{ml}$ ), the same authors reported that the capacity of the oil overlay to absorb the steroid was close to being saturated before the oocytes were added, thus sustaining an adequate concentration of between 211 and $48 \mathrm{ng} / \mathrm{ml}$ for the duration of oocyte culture (Zheng et al. 2003). In the present study, having established that $\mathrm{P}_{4}$ was depleted rapidly from the medium in the presence of oil, we chose to eliminate the oil completely to avoid any ambiguity in the results.

Irrespective of the concentration used, $\mathrm{P}_{4}$ supplementation during in vitro culture had no effect on the proportion of zygotes developing to the blastocyst stage or on the quality of the blastocysts as assessed in 
Table 3 Total, inner cell mass (ICM) and trophectoderm (TE) cell numbers (mean \pm S.E.M.) in Day 7 bovine blastocysts produced in vitro in the absence or presence of progesterone $\left(1 \times 10^{-7} \mathrm{M}\right)$.

\begin{tabular}{lcr}
\hline & Control & Progesterone \\
\hline No. of blastocysts & 42 & 32 \\
Total nuclei & $145.28 \pm 4.71$ & $137.91 \pm 6.18$ \\
No ICM nuclei & $34.33 \pm 1.15$ & $36.19 \pm 1.83$ \\
$\%$ ICM & $24.13 \pm 0.81$ & $26.64 \pm 1.11$ \\
No TE nuclei & $110.95 \pm 4.30$ & $101.72 \pm 5.30$ \\
$\%$ TE & $75.87 \pm 0.81$ & $73.36 \pm 1.11$ \\
ICM/TE & $0.33 \pm 0.01$ & $0.37 \pm 0.02$ \\
\hline
\end{tabular}

$P>0.05$.

terms of cell number and allocation within the blastocyst or relative transcript abundance for a selected number of genes. Similarly, Pereira et al. (2009) failed to demonstrate a direct association between high $\mathrm{P}_{4}$ concentrations and embryo survival. This apparent lack of an effect on blastocyst development is consistent with previous observations from our group. For example, Carter et al. (2008), reported no effect on the recovery of blastocysts on Day 7 from single-ovulating animals with normal or elevated $\mathrm{P}_{4}$ concentrations despite a clear advancement of post hatching elongation. In addition, Rings et al. (2008) reported no effect on blastocyst yield following the endoscopic transfer of in vitro produced zygotes to the ipsilateral oviduct of heifers with normal or elevated $\mathrm{P}_{4}$ concentrations. Taken together, these results would strongly suggest that $\mathrm{P}_{4}$ is not associated with the ability of the oocyte to form a blastocyst.

Extending the above data, we addressed the question of whether an effect of $\mathrm{P}_{4}$ could be manifested post hatching by transferring blastocysts produced in the absence or presence of $\mathrm{P}_{4}$ to synchronized recipients. We chose Day 14 to slaughter the animals as it represents the initiation of elongation in cattle, a critical checkpoint in development. In addition, previous personal experience has shown that in the case of multiple transfers of embryos as carried out here, separating rapidly elongating conceptuses after Day 14 can be extremely difficult. Lastly, but perhaps most importantly, it is known that very little embryonic loss occurs after Day 14 in cattle (Dunne et al. 2000) and thus survival to Day 14 represents a useful measure of developmental competence. Consistent with the data on blastocyst formation described above, culture in the presence of $\mathrm{P}_{4}$ to the blastocyst stage and subsequent transfer to recipients did not lead to an advancement in conceptus length by Day 14 . Blood samples from all recipients from Day 0 to Day 14 indicated no difference between those receiving control or $\mathrm{P}_{4}$-treated embryos, thus ruling out any potential effect of recipient $\mathrm{P}_{4}$ concentration on embryo development as previously described (Lonergan et al. 2007). These observations are perhaps not that surprising when one considers that it is possible to transfer embryos produced in vitro in the absence of $\mathrm{P}_{4}$, and achieve acceptable pregnancy rates.

Given that we have previously shown that elevating $\mathrm{P}_{4}$ in heifers in a manner identical to that described in the present study leads to a significant alteration in the transcriptome of the endometrium (Forde et al. 2009), the final experiment addressed the question of whether elevating $\mathrm{P}_{4}$ in vivo for a short window (Day 3-7) prior to embryo transfer would create an environment capable of advancing the development of blastocysts transferred to the uterus on Day 7. In other words, does the embryo need to be present during the period of elevated $\mathrm{P}_{4}$ in vivo in order to benefit from it? In contrast to the results of Experiment 5, transfer of blastocysts to a high $\mathrm{P}_{4}$ environment on Day 7 lead to a fourfold increase in conceptus length on Day 14. This provides clear evidence to support the hypothesis that $\mathrm{P}_{4}$-induced changes in the uterine environment are responsible for the advancement in conceptus elongation reported previously in cattle (Garrett et al. 1988, Carter et al. 2008) and sheep (Satterfield et al. 2006) and, interestingly, the embryo does not need to be present during the period of high $\mathrm{P}_{4}$ in order to exhibit advanced elongation.

In conclusion, taking these results together with those from previous studies, it would appear that $\mathrm{P}_{4}$ either in vivo (Carter et al. 2008, Rings et al. 2008) or in vitro (present study) does not affect the ability of embryos to develop to the blastocyst stage in cattle. Furthermore, exposure to $\mathrm{P}_{4}$ in vitro does not affect the post-hatching elongation of the embryo following transfer to a recipient. In contrast, however, transfer of a blastocyst to a uterine environment previously primed by elevated $\mathrm{P}_{4}$ results in a significant advancement in conceptus elongation consistent with an increase in interferon- $\tau$ production and a stronger signal around the critical time of maternal recognition of pregnancy. Given our knowledge of $\mathrm{P}_{4}$-induced changes in endometrial gene expression, future studies will focus on the composition of uterine histotroph in an effort to identify secreted factors associated with the stimulation of conceptus growth.

Table 4 Development of bovine blastocysts produced in vitro in the absence or presence of progesterone $\left(\mathrm{P}_{4}, 10 \times 10^{-7} \mathrm{M}\right)$ following transfer (in groups of 20 blastocysts) to synchronized recipients on Day 7 and recovery on Day 14 (Experiment 5).

\begin{tabular}{lccccc}
\hline & $\boldsymbol{N}$ & $\begin{array}{c}\text { Cleaved, } \boldsymbol{n} \\
(\text { mean } \pm \text { S.E.M.\%) }\end{array}$ & $\begin{array}{c}\text { Blastocyst yield, } \boldsymbol{n} \\
(\text { mean } \pm \text { S.E.M.\%) }\end{array}$ & $\begin{array}{c}\text { No. of } \\
\text { recipients }\end{array}$ & $\begin{array}{c}\text { No. of embryos recovered } \\
(\text { recovery rate \%) }\end{array}$ \\
\hline $\begin{array}{l}\text { Control } \\
+P_{4}\end{array}$ & 1659 & $1208(72.7 \pm 1.91)$ & $412(24.6 \pm 1.60)$ & 12 & $121(50.4 \pm 5.35)$ \\
\hline
\end{tabular}



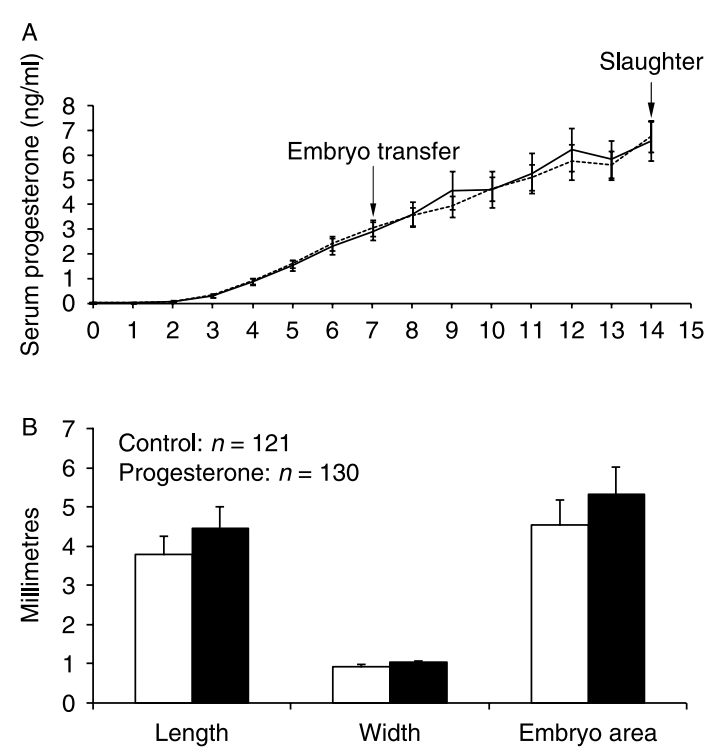

Figure 4 Mean ( \pm s.E.M.) serum progesterone concentration in recipient heifers (A) and Day 14 embryo dimensions (B) following transfer of Day 7 blastocysts produced in vitro in the absence or presence of progesterone $\left(1 \times 10^{-7} \mathrm{M}\right)$ to synchronized recipients and recovery at slaughter on Day 14. Each recipient received 20 blastocysts which had been produced in vitro in the presence (dashed line, black bars) or absence (solid line, white bars) of exogenous progesterone. Note that, as expected, the progesterone profiles for both heifer groups are similar, irrespective of embryo type transferred. Exposure to progesterone in vitro did not affect the embryo dimensions on Day $14(P>0.05)$.

\section{Materials and Methods}

All experimental procedures involving animals were licensed by the Department of Health and Children, Ireland, in accordance with the Cruelty to Animals Act (Ireland 1897) and European Community Directive 86/609/EC.

\section{In vitro embryo production}

Unless otherwise stated, all chemicals were purchased from Sigma Chemical Company. The techniques for producing embryos in vitro have been previously described in detail (Rizos et al. 2002). Immature cumulus oocyte complexes (COCs) were obtained by aspirating follicles from the ovaries of heifers and cows collected at slaughter. COCs were matured for $24 \mathrm{~h}$ in TCM-199 supplemented with $10 \%(\mathrm{v} / \mathrm{v})$ FCS and $10 \mathrm{ng} / \mathrm{ml}$ epidermal growth factor at $39{ }^{\circ} \mathrm{C}$ under an atmosphere of $5 \%$ $\mathrm{CO}_{2}$ in air with maximum humidity. For IVF, matured COCs were inseminated with frozen-thawed percoll-separated bull sperm at a concentration of $1 \times 10^{6}$ spermatozoa $/ \mathrm{ml}$. Gametes were co-incubated at $39{ }^{\circ} \mathrm{C}$ under an atmosphere of $5 \% \mathrm{CO}_{2}$ in air with maximum humidity. Semen from the same bull was used for all experiments.

At $\sim 20 \mathrm{~h}$ post insemination (pi), presumptive zygotes were denuded, divided into groups of 40-50, and transferred to $500 \mu \mathrm{l}$ culture wells. The basal medium for all embryo culture was SOF supplemented with $5 \%$ FCS. Depending on the experiment (see below), this was supplemented or not with $\mathrm{P}_{4}$ and/or with BOECs. Cleavage rate was recorded at $48 \mathrm{hpi}$ and blastocyst development recorded at Days 6, 7, and 8 pi. All Day 7 blastocysts were snap frozen in groups of ten in liquid nitrogen and stored at $-80^{\circ} \mathrm{C}$ for mRNA extraction and realtime quantitative RT-PCR.

\section{Preparation of BOEC monolayer}

Ipsilateral oviducts were collected from slaughtered heifers at the mid-luteal phase of the estrous cycle and transported to the laboratory on ice. Each oviduct was flushed with $10 \mathrm{ml}$ of SOF $+5 \%$ FCS. Oviduct cells were centrifuged at $750 \boldsymbol{g}$ for $9 \mathrm{~min}$ and the resulting pellet was washed by centrifugation at $100 \mathrm{~g}$ for $5 \mathrm{~min}$ in $5 \mathrm{ml}$ of the same medium. The final pellet was re-suspended in culture medium and the cells separated by pipetting. Oviduct cells were counted in a hemocytometer and diluted in the appropriate volume of culture medium to give a final concentration of $1 \times 10^{6} \mathrm{cells} / \mathrm{ml}$. Culture wells $(500 \mu \mathrm{l})$ were then prepared from this solution and used for embryo culture 4-5 days later. Half of the media was replenished every $48 \mathrm{~h}$ before and during embryo culture.

\section{Differential staining of blastocysts}

Differential staining of ICM and TE cells was carried out using published procedures (Thouas et al. 2001) with minor modifications. For partial permeabilization and staining of TE, blastocysts were incubated in $300 \mu$ of PBS with $0.2 \%$ Triton $\mathrm{X}-100$ and $100 \mu \mathrm{g} / \mathrm{ml}$ propidium iodine in the dark for $50 \mathrm{~s}$ at room temperature. For fixation and total cell staining, blastocysts were then immediately transferred into $300 \mu \mathrm{l}$ $100 \%$ ethanol containing $25 \mu \mathrm{g} / \mathrm{ml}$ bisbenzimide (Hoechst 33342) for $3 \mathrm{~min}$ at room temperature. Fixed and stained blastocysts were then transferred directly into glycerol, taking care to avoid carryover of excessive amounts of fixative
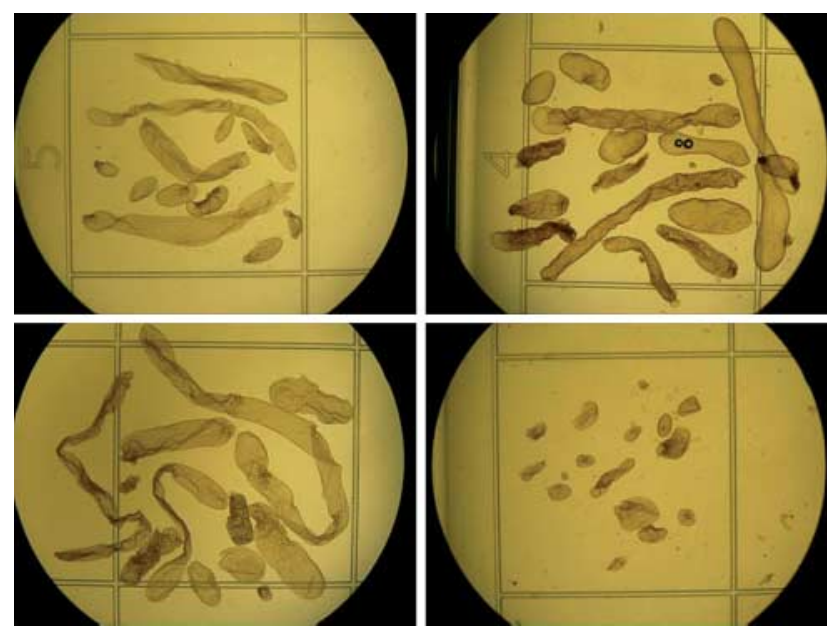

Figure 5 Representative images of Day 14 elongating bovine embryos recovered from four individual heifers following the transfer of 20 blastocysts on Day 7. The images show the type of variation and recovery one can expect following such multiple embryo transfer. For scale, the square grid in the dish is $13 \times 13 \mathrm{~mm}$. 
Table 5 Development of bovine blastocysts produced in vitro in the absence of progesterone $\left(\mathrm{P}_{4}\right)$ following transfer on Day 7 (in groups of 20 blastocysts) to synchronized recipients with normal or elevated $\mathrm{P}_{4}$ and recovery on Day 14 (Experiment 6).

\begin{tabular}{|c|c|c|c|c|c|}
\hline$N$ & $\begin{array}{c}\text { Cleaved, } \boldsymbol{n} \\
(\text { mean } \pm \text { s.E.M.\%) }\end{array}$ & $\begin{array}{c}\text { Blastocyst yield, } \boldsymbol{n} \\
(\text { mean } \pm \text { S.E.M.\%) }\end{array}$ & & $\begin{array}{l}\text { No. of } \\
\text { recipients }\end{array}$ & $\begin{array}{c}\text { No. of embryos recovered, } \boldsymbol{n} \\
\text { (recovery rate \%) }\end{array}$ \\
\hline 1817 & $1527(84.2 \pm 0.92)$ & $527(29.7 \pm 1.53)$ & $\begin{array}{l}\text { Normal } \mathrm{P}_{4} \\
\mathrm{High}_{4}\end{array}$ & $\begin{array}{l}9 \\
9\end{array}$ & $\begin{array}{r}112(61.7 \pm 5.89) \\
79(43.9 \pm 7.49)\end{array}$ \\
\hline
\end{tabular}

Elevated progesterone was achieved by insertion of a PRID on Day 3 of the estrous cycle. See Materials and Methods for a detailed description.

solution. Finally, blastocysts were mounted onto a glass microscope slide in a drop of glycerol, gently flattened with a cover slip and visualized for cell counting under a fluorescence microscope.

\section{$\boldsymbol{P}_{4}$ assays}

Following collection, blood samples were refrigerated $\left(4^{\circ} \mathrm{C}\right)$ for $12-24 \mathrm{~h}$ before being centrifuged at $1500 \mathrm{~g}$ at $4{ }^{\circ} \mathrm{C}$ for $20 \mathrm{~min}$. Serum was separated and stored at $-20^{\circ} \mathrm{C}$ until assayed to determine $\mathrm{P}_{4}$ concentration by solid phase RIA using a Coat-A-Count Progesterone kit (Siemens Medical Solutions Diagnostics, Los Angeles, CA, USA). The sensitivity of the assay was $0.03 \mathrm{ng} / \mathrm{ml}$. The intra- and interassay coefficients of variation for assays of $\mathrm{P}_{4}$ (low, medium, and high samples) were $8.5,4.8,4.9,10,4.9$, and $5 \%$ respectively.

In order to determine $\mathrm{P}_{4}$ concentrations in spent culture media and in oviductal flushings an ELISA kit, prepared for
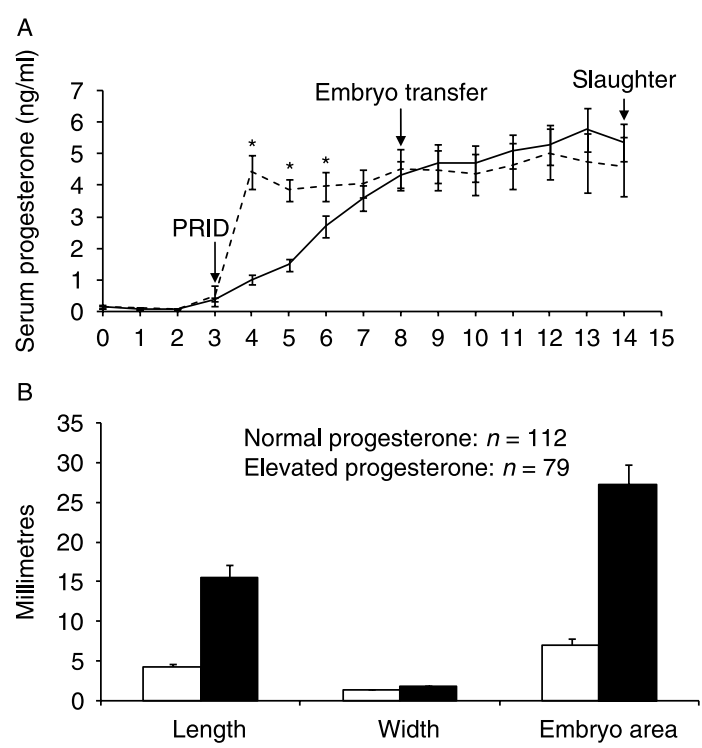

Figure 6 Mean ( \pm S.E.M.) serum progesterone concentration in recipient heifers (A) and Day 14 embryo dimensions (B) following transfer of Day 7 in vitro produced blastocysts to synchronized recipients with normal (solid line, white bars) or elevated (dashed line, black bars) progesterone concentrations and recovery at slaughter on Day 14 . Elevated progesterone concentrations were achieved using a previously validated model (Carter et al. 2008) involving insertion of a PRID on Day 3 of the estrous cycle. Each recipient received 20 blastocysts which had been produced in vitro in the absence of progesterone. Elevated progesterone was associated with a significant increase in mean embryo dimensions $(P<0.05)$. human serum or plasma, (DE1561 DIMEDITEC Diagnostics $\mathrm{GmbH}$, Kiel, Germany) was used. Inter and intra-assay coefficients of variation were 6.63 and $6.42 \%$ respectively.

\section{RNA extraction, $R T$, and quantification of $m R N A$ transcript abundance}

For the analysis of the expression of mRNA for PGRs across development, RNA was extracted from pools of ten immature oocytes, 2- to 4-cell, 8-cell, 16-cell, morula and blastocyst stage embryos. To assess the effect of culture with $\mathrm{P}_{4}$ on mRNA abundance of candidate transcripts in blastocysts and in co-cultured oviduct cells, three pools of ten Day 7 blastocysts or oviduct cells from each experimental group were snap frozen.

Poly(A) RNA was prepared following the manufacturer's instructions using the Dynabeads mRNA Direct Extraction KIT (Dynal Biotech, Oslo, Norway). To take account of potential differences in RNA content between different developmental stages, after adding the lysis buffer, $0.1 \mathrm{pg}$ rabbit globin mRNA (Sigma) was added to each tube as an internal standard. The RT reaction was carried out following the manufacturer's instructions (Promega) using poly $(\mathrm{T})$ anchored primers and AMV reverse transcriptase enzyme in a volume of $20 \mu \mathrm{l}$ to prime the RT reaction and to produce cDNA. Tubes were heated to $70{ }^{\circ} \mathrm{C}$ for $5 \mathrm{~min}$ to denature the secondary RNA structure and then the RT mix was completed with the addition of 5 units of Superscript RT enzyme. They were then incubated at room temperature for $10 \mathrm{~min}$ and then at $42{ }^{\circ} \mathrm{C}$ for $60 \mathrm{~min}$ to allow the RT of RNA, followed by $70^{\circ} \mathrm{C}$ for $10 \mathrm{~min}$ to denature the RT enzyme.

The quantification of all mRNA transcripts was carried out by real-time quantitative PCR (qPCR) as previously described (Bermejo-Alvarez et al. 2008). Three replicate qPCR experiments were conducted for all genes of interest. To examine mRNA expression in blastocysts and BOEC, experiments were conducted to contrast relative levels of each transcript and histone (H2AFZ) in every sample. qPCR was performed by adding a $2.5 \mu \mathrm{l}$ aliquot of each sample to the PCR mix containing the specific primers to amplify $H 2 A F Z, B C L 2$-associated $X$ protein $(B A X), B C L 2$-like 1 (BCL2L1), Src homology 2 domain containing transforming protein C1 (SHC1SHC or P66), tumor protein p53 (TP53), genes related to apoptosis, thioredoxin $(T X N)$, aldo-ketoreductase family 1 -member 1 (AKR1B1), prostaglandinendoperoxidase-2 (COX-2 or PTGS2), genes related to metabolism, placenta-specific 8 (PLAC8), related to implantation, and POU class 5 homeobox 1 (OCT3/4 or POU5F1) 
related to pluripotency. To compare mRNA expression of PGRs (PGR, PGRMC1, and PGRMC2) in embryos at different developmental stages, the experiments were conducted to contrast relative levels of each transcript and rabbit globin $(H B A)$ in each sample. Primer sequences and the sizes of the amplified fragments of all transcripts are shown in Table 6. The comparative $C_{\mathrm{T}}$ method was used to quantify expression levels (Rizos et al. 2007). Quantification was normalized to the endogenous control, $H 2 A F Z$ (when expression between blastocysts and BOEC monolayer was carried out) or to an exogenous control ( $H B A$; when expression between embryos at different developmental stages was carried out). Fluorescence was acquired in each cycle to determine the threshold cycle or the cycle during the log-linear phase of the reaction at which fluorescence increased above background for each sample. Within this region of the amplification curve, a difference of one cycle is equivalent to doubling of the amplified PCR product. According to the comparative $C_{\mathrm{T}}$ method, the $\Delta C_{\mathrm{T}}$ value was determined by subtracting the control gene $(H 2 A F Z$ or $H B A) C_{\mathrm{T}}$ value for each sample from each gene $C_{\mathrm{T}}$ value of the sample. Calculation of $\Delta \Delta C_{\mathrm{T}}$ involved using the highest sample $\Delta C_{\mathrm{T}}$ value (i.e. the sample with the lowest target expression) as an arbitrary constant to subtract from all other $\Delta C_{\mathrm{T}}$ sample values. Fold changes in the relative gene expression of the target were determined using the formula $2^{-\Delta \Delta C_{\mathrm{T}}}$.

\section{PGR mRNA copy number quantification in Day 7 blastocysts}

In addition to the above, an absolute quantification method was used to measure the presence and copy number of $P G R$, $P G R M C 1$, and $P G R M C 2$ in Day 7 blastocysts. Three groups of ten blastocysts from different experimental replicates were used. Quantification of PGR mRNA copy number in each sample was done using a standard curve for each receptor type. To generate the copy number standard curve for cDNA standards, PGR cDNA was amplified by PCR from mRNA purified from BOECs. PCR products were purified from an agarose gel according to the manufacturer's protocol (Elu-quick DNA purification kit, Whatman, Stanford, ME, USA). Following the confirmation of the PCR product by ethidium bromide-stained $2 \%$ agarose gel electrophoresis, the expected fragments were eluted and the concentration of the PCR fragments was determined spectrophotometrically by measuring absorbance at $260 \mathrm{~nm}$. The standards in triplicate and cDNA samples (equivalent to 0.66 embryos per sample) were then co-amplified in the same reaction prepared from a master mix. Copy numbers of fragments were empirically determined using the following equation: copy number of PCR standard $=$ mole $\times$ Avogadro Constant $=$ grams $/$ fragment molecular weight $\times$ Avogadro Constant (Avogadro Constant $\left.=6.0221367 \times 10^{23}\right)$. The quantified PCR fragments were later serially diluted in five 10-fold serial-dilutions

Table 6 Details of primers used for quantitative real-time PCR.

\begin{tabular}{|c|c|c|c|c|}
\hline Gene symbol & MGI official name & Primer sequence $\left(5^{\prime}-3^{\prime}\right)$ & $\begin{array}{l}\text { Fragment } \\
\text { size }\end{array}$ & $\begin{array}{l}\text { GenBank } \\
\text { accession no. }\end{array}$ \\
\hline$H 2 A F Z$ & $\mathrm{H} 2 \mathrm{~A}$ histone family, member $\mathrm{Z}$ & $\begin{array}{l}\text { 5'-AGGACGACTAGCCATGGACGTGTG } \\
5^{\prime} \text {-CCACCACCAGCAATTGTAGCCTTG }\end{array}$ & 212 & NM_174809 \\
\hline$B A X$ & BCL2-associated X protein & $\begin{array}{l}\text { 5'-CTACTTTGCCAGCAAACTGG } \\
5^{\prime} \text {-TCCCAAAGTAGGAGAGGA }\end{array}$ & 158 & NM_173894.1 \\
\hline$B C L 2 L 1$ & BCL2-like 1 & $\begin{array}{l}\text { 5'-GGAGCTGGTGGTTGACTTTC } \\
5^{\prime} \text {-CTAGGTGGTCATTCAGGTAAG }\end{array}$ & 517 & BC147863.1 \\
\hline SHC1SHC & $\begin{array}{l}\text { Src homology } 2 \text { domain containing } \\
\text { transforming protein c1 }(P 66)\end{array}$ & $\begin{array}{l}\text { 5'-GTGAGGTCTGGGGAGAAGC } \\
\text { 5'-GGTTCGGACAAAGGATCACC }\end{array}$ & 334 & NM_001075305 \\
\hline TP53 & Tumor protein p53 & $\begin{array}{l}5^{\prime} \text {-СTCAGTCCTCTGCCATACTA } \\
5^{\prime} \text {-GGATCCAGGATAAGGTGAGC }\end{array}$ & 364 & U74486 \\
\hline$T X N$ & Thioredoxin & $\begin{array}{l}\text { 5'-ATGGTGAAACAGATTGAGAGCA } \\
5^{\prime} \text {-CGTTGGAATACTTTTCAGAGAGAGAA }\end{array}$ & 154 & AF104105 \\
\hline$A K R 1 B 1$ & Aldo-keto-reductase family 1 -member 1 & $\begin{array}{l}\text { 5'-CGTGATCCCCAAGTCAGTGA } \\
5^{\prime} \text {-AATCCCTGTGGGAGGCACA }\end{array}$ & 152 & M31463.1 \\
\hline PTGS2 & $\begin{array}{l}\text { Prostaglandin-endoperoxide } \\
\text { synthase } 2 \text { (COX2) }\end{array}$ & $\begin{array}{l}\text { 5'-ATCTACCCGССТСАTGTTCCT } \\
\text { 5'-GGATTAGССTGСTTGTCTGGA }\end{array}$ & 187 & AF031698 \\
\hline PLAC8 & Placenta-specific 8 & $\begin{array}{l}\text { 5'-CGGTGTTCCAGAGGTTTTTCC } \\
5^{\prime} \text {-AAGATGCCAGTCTGCCAGTCA }\end{array}$ & 163 & NM_016619 \\
\hline POU5F1 & POU class 5 homeobox 1 (OCT3/4) & $\begin{array}{l}\text { 5'-CGAGTATCGAGAACCGAGTG } \\
\text { 5'-CAGGGTTCTCTCССTAGCTC }\end{array}$ & 440 & NM_174580.1 \\
\hline$H B A$ & Alpha-hemoglobine & $\begin{array}{l}\text { 5'-GCAGCCACGGTGTCGAGTAT } \\
5^{\prime} \text {-GTGGGACAGGAGCTTGAAAT }\end{array}$ & 257 & X04751 \\
\hline$P G R$ & Progesterone receptor & $\begin{array}{l}5^{\prime} \text {-GAGAGCTCATCAAGGCAATTGG } \\
5^{\prime} \text {-CACCATCCСТGCCAАTATCTTG }\end{array}$ & 227 & XM_583951.4 \\
\hline PGRMC1 & $\begin{array}{l}\text { Progesterone receptor membrane } \\
\text { component } 1\end{array}$ & $\begin{array}{l}\text { 5'-TGTGTGTCACAAATCCAGAAAG } \\
\text { 5'-AATCATGCAGTTAGGTCAATCG }\end{array}$ & 265 & AF254804 \\
\hline PGRMC2 & $\begin{array}{l}\text { Progesterone receptor membrane } \\
\text { component } 2\end{array}$ & $\begin{array}{l}\text { 5'-AGGAGAGGTGAGGGTGTCCATC } \\
\text { 5'-TTTCAAATGATCTTGCTGTTGGG }\end{array}$ & 206 & NM_001099060 \\
\hline
\end{tabular}


increments and were used as known copy-number template standards in qPCR. Fluorescence was acquired at each cycle in order to determine the threshold cycle or the cycle during the log-linear phase of the reaction at which fluorescence rises above background for each sample. The Rotor-Gene quantification software generates a best-fit line and determines unknown concentrations by interpolating the noise-band intercept of an unknown sample against the standard curve of known concentrations. Reverse-transcriptase negative controls (samples containing RNA to which reverse transcriptase was not added) were included to exclude PCR amplification of contaminating genomic DNA.

\section{Statistical analysis}

Data were analyzed using the SigmaStat (Jandel Scientific, San Rafael, CA, USA) software package. One-way repeatedmeasures ANOVA (followed by multiple pair-wise comparisons using Student-Newman-Kleus method) was used for the analysis of differences in embryo development (cleavage rate, blastocyst yield), ratio of ICM to TE cells, recovery rate of embryos on Day 14 and also for the analysis of differences in mRNA expression. Blastocyst cell numbers, serum $\mathrm{P}_{4}$, and embryo dimensions on Day 14 were compared with Students $t$-test.

\section{Experiment 1: PGR mRNA in bovine embryos}

The aim of this experiment was to determine the presence of mRNA for three PGRs (PGR, PGRMC1, and PGRMC2) during early bovine embryo development. Three groups of ten immature oocytes and in vitro produced bovine embryos were removed from culture at the 2- to 4-cell, 8-cell, 16-cell, morula and blastocyst stage, snap-frozen in groups of 10 in liquid nitrogen and stored at $-80{ }^{\circ} \mathrm{C}$ until analysis. In addition, three groups of ten blastocysts from different experimental replicates were used to determine the copy number of $P G R$, PGRMC1, and PGRMC2 in Day 7 blastocysts.

\section{Experiment 2: $P_{4}$ concentration in bovine oviduct flushings}

In order to get an estimate of the concentration of $\mathrm{P}_{4}$ to which the embryo might normally be exposed in vivo (as opposed to serum concentrations), bovine oviducts $(n=23)$ were collected from animals slaughtered at the mid-luteal phase of the estrous cycle (assessed by the presence of a large functional corpus luteum) and transferred on ice to the laboratory. All oviducts were trimmed and flushed slowly with $2 \mathrm{ml}$ PBS; to maximize $\mathrm{P}_{4}$ recovery, the PBS was left in the oviduct for up to 5 min before recovery. $\mathrm{P}_{4}$ concentration was determined as described above.

\section{Experiment 3: effect of culture system on $\mathrm{P}_{4}$ concentration in culture medium}

It is known that steroids are lipophilic in nature and use of oil during culture can result in their depletion from the medium (Shimada et al. 2002). Before progressing to experiments examining the addition of $\mathrm{P}_{4}$ to culture on embryo development, the aim of this experiment was to assess the effect of culture system on the rate of disappearance of $\mathrm{P}_{4}$ from culture medium. Following addition of a known quantity $\left(1 \times 10^{-7} \mathrm{M}\right)$ of $\mathrm{P}_{4}$ to the culture medium on Day 1 , the concentration remaining on Days 3, 5, and 7 of culture was assessed. Culture conditions tested included: i) $25 \mu \mathrm{l}$ droplets of SOF under mineral oil, the system of culture routinely used on our laboratory ii) $500 \mu$ I SOF in wells (without embryos), iii) $500 \mu \mathrm{l} \mathrm{SOF}$ in wells with embryos, iv) $500 \mu \mathrm{l} \mathrm{SOF}$ in co-culture with BOEC (without embryos) and v) $500 \mu \mathrm{l} \mathrm{SOF}$ in co-culture with BOEC with replacement of half of the media every 2 days (without embryos).

\section{Experiment 4: effect of $P_{4}$ supplementation of culture medium on embryo development and quality}

The aim of this experiment was to determine the effect of exogenous $\mathrm{P}_{4}$ added during in vitro culture on the proportion of embryos reaching the blastocyst stage and on blastocyst quality measured as the relative mRNA abundance of selected genes related to quality. Bovine zygotes produced by IVM/IVF were cultured in SOF alone ( $n=1627 ; 9$ replicates) or in co-culture with BOEC ( $n=1312 ; 7$ replicates) in the absence or presence of $\mathrm{P}_{4}$ at one of three concentrations $\left(0.1,1\right.$ or $10 \times 10^{-7} \mathrm{M}$, equivalent to $3.15,31.5$, and $315 \mathrm{ng} / \mathrm{ml}$ respectively). A vehicle control containing an equivalent amount of ethanol used to prepare the $\mathrm{P}_{4}$ stock solution was included initially to eliminate the effect of ethanol $(n=194)$. Day 7 blastocysts from each group were snap-frozen in liquid nitrogen in groups of 10 for mRNA extraction. Also, BOEC from each group were isolated on Day 7 using $100 \mu$ l lysis buffer and snap-frozen for mRNA extraction. Quantification of transcripts for $B A X$, BCL2L1, SHC1SHC, TP53, TXN, AKR1B1, COX2, PLAC8, and POU5F1 was carried out by real-time qRT-PCR. These genes have been previously associated with likelihood of pregnancy after embryo transfer in cattle (El-Sayed et al. 2006).

\section{Experiment 5: effect of exposure to $\mathrm{P}_{4}$ in vitro on survival and elongation of blastocysts in vivo following embryo transfer}

As mentioned above, there is clear evidence for an association between circulating $\mathrm{P}_{4}$ concentration and advanced conceptus elongation (Garrett et al. 1988, Carter et al. 2008). In order to test the hypothesis that exposure to $\mathrm{P}_{4}$ during early development in vitro (zygote to blastocyst stage) would affect posthatching elongation, zygotes produced by IVM/IVF were cultured in the absence $(n=1659)$ or presence $(n=1876)$ of $10 \times 10^{-7} \mathrm{MP}_{4}$ (4 replicates). Although higher than normal physiological concentrations, this dose was chosen to maximize the likelihood of observing an effect if one should exist. Based on the results of Experiment 3, medium was replenished every 2 days to maintain $\mathrm{P}_{4}$ concentrations. Blastocyst development was recorded and Day 7 blastocysts $(n=440)$ were transferred to the uteri of synchronized recipients (20 blastocysts per recipient). Twenty-two crossbred beef heifers were used as recipients (predominantly Charolais or Limousin cross; 18-24 months old). Animals were housed indoors on slats for the duration of the experiment and were fed a diet 
consisting of grass and maize silage supplemented with a standard beef ration. Estrous cycles were synchronized by administration of two i.m. injections of the prostaglandin $F_{2 \alpha}$ analogue, cloprostenol (PG; Estrumate; Chanelle, Loughrea, Galway, Ireland), 11 days apart. Standing estrus was defined as Day 0 . A total of 20 in vitro-produced blastocysts produced in the presence or absence of $\mathrm{P}_{4}$ were transferred to each recipient on Day 7 (control, $n=12 ; \mathrm{P}_{4}$-treated, $n=10$ ) and all recipients were slaughtered on Day 14 to assess embryo survival. A daily blood sample was taken from all animals by jugular venipuncture from Day 0 to Day 14 to establish the recipient $\mathrm{P}_{4}$ profile in order to ensure that all animals had similar endogenous $\mathrm{P}_{4}$ concentrations. Following slaughter, the reproductive tract was removed, sealed in a plastic bag and placed in a sealed polystyrene box for transportation to the laboratory (within $60 \mathrm{~min}$ ). After removal of the ovaries and the oviducts the uterine horns were trimmed free of excess tissue before being flushed with $40 \mathrm{ml}$ PBS. Embryos were located under a stereomicroscope, measured and then snap frozen individually in liquid nitrogen and stored at $-80{ }^{\circ} \mathrm{C}$. From each replicate a representative number of Day 7 blastocysts from both groups was processed as described above for assessment of cell number (control: $n=42 ; \mathrm{P}_{4}: n=32$ ).

\section{Experiment 6: effect of elevated $P_{4}$ in vivo on survival and elongation of bovine blastocysts following embryo transfer}

In order to test the hypothesis that a modified uterine environment induced by artificially elevated circulating $\mathrm{P}_{4}$ is capable of advancing the post-hatching elongation of Day 7 blastocysts, groups of 20 blastocysts produced in vitro in the absence of $\mathrm{P}_{4}$ were transferred to synchronized recipient heifers with normal $(n=9)$ or elevated $(n=9) \mathrm{P}_{4}$ concentrations. To obtain divergent $\mathrm{P}_{4}$ concentrations in heifers, a validated model was used where approximately half of the animals received a PRID (containing $1.55 \mathrm{~g} \mathrm{P}_{4}$; CEVA Animal Health Ltd, Chesham, UK) on Day 3 of the estrous cycle as previously described (Carter et al. 2008). A daily blood sample was taken from all animals by jugular venipuncture from Day 0 to Day 14 to establish the recipient $\mathrm{P}_{4}$ profile. All heifers were slaughtered on Day 14 and elongating conceptuses were recovered and measured as described above.

\section{Declaration of interest}

The authors declare that there is no conflict of interest that could be perceived as prejudicing the impartiality of the research reported.

\section{Funding}

This work was supported by Science Foundation Ireland, Grant 06/IN1/B62 (the opinions, findings and conclusions or recommendations expressed in this material are those of the authors and do not necessarily reflect the views of the Science Foundation Ireland). Dimitrios Rizos is supported by the Spanish Ministry of Science and Technology (AGL200605616) and INIA (AT2006-003). Maria Clemente was supported by a scholarship from INIA.

\section{Acknowledgements}

The authors thank M Wade, P Duffy, and Penny Furney for their excellent technical assistance.

\section{References}

Ashworth CJ, Sales DI \& Wilmut I 1989 Evidence of an association between the survival of embryos and the periovulatory plasma progesterone concentration in the ewe. Journal of Reproduction and Fertility 87 23-32.

Bauersachs S, Ulbrich SE, Gross K, Schmidt SE, Meyer HH, Wenigerkind H, Vermehren M, Sinowatz F, Blum H \& Wolf E 2006 Embryo-induced transcriptome changes in bovine endometrium reveal species-specific and common molecular markers of uterine receptivity. Reproduction 132 319-331.

Bermejo-Alvarez P, Rizos D, Rath D, Lonergan P \& Gutierrez-Adan A 2008 Epigenetic differences between male and female bovine blastocysts produced in vitro. Physiological Genomics 32 264-272.

Carter F, Forde N, Duffy P, Wade M, Fair T, Crowe MA, Evans AC, Kenny DA, Roche JF \& Lonergan P 2008 Effect of increasing progesterone concentration from Day 3 of pregnancy on subsequent embryo survival and development in beef heifers. Reproduction, Fertility, and Development 20 368-375.

Chagas e Silva J \& Lopes da Costa L 2005 Luteotrophic influence of early bovine embryos and the relationship between plasma progesterone concentrations and embryo survival. Theriogenology 64 49-60.

Conneely OM, Mulac-Jericevic B, DeMayo F, Lydon JP \& O'Malley BW 2002 Reproductive functions of progesterone receptors. Recent Progress in Hormone Research 57 339-355.

Diskin MG \& Morris DG 2008 Embryonic and early foetal losses in cattle and other ruminants. Reproduction in Domestic Animals 43 260-267.

Dode MA, Dufort I, Massicotte L \& Sirard MA 2006 Quantitative expression of candidate genes for developmental competence in bovine two-cell embryos. Molecular Reproduction and Development 73 288-297.

Dunne LD, Diskin MG \& Sreenan JM 2000 Embryo and foetal loss in beef heifers between day 14 of gestation and full term. Animal Reproduction Science 58 39-44.

El-Sayed A, Hoelker M, Rings F, Salilew D, Jennen D, Tholen E, Sirard MA, Schellander K \& Tesfaye D 2006 Large-scale transcriptional analysis of bovine embryo biopsies in relation to pregnancy success after transfer to recipients. Physiological Genomics 28 84-96.

Engmann L, Losel R, Wehling M \& Peluso JJ 2006 Progesterone regulation of human granulosa/luteal cell viability by an RU486-independent mechanism. Journal of Clinical Endocrinology and Metabolism 91 4962-4968.

Falkenstein E, Meyer C, Eisen C, Scriba PC \& Wehling M 1996 Full-length cDNA sequence of a progesterone membrane-binding protein from porcine vascular smooth muscle cells. Biochemical and Biophysical Research Communications 229 86-89.

Ferguson CE, Davidson TR, Mello MRB, Lima AS, Kesler DJ, Wheeler MB \& Godke RA 2005 Evidence for a direct effect of $\mathrm{P}_{4}$ on IVF-derived bovine 8-cell embryos. Reproduction, Fertility, and Development 17219.

Forde N, Carter F, Fair T, Crowe MA, Evans AC, Spencer TE, Bazer FW, McBride R, Boland MP, O'Gaora P et al. 2009 Progesterone-regulated changes in endometrial gene expression contribute to advanced conceptus development in cattle. Biology of Reproduction [in press]. DOI: 10.1095/biolreprod.108.074336.

Garrett JE, Geisert RD, Zavy MT \& Morgan GL 1988 Evidence for maternal regulation of early conceptus growth and development in beef cattle. Journal of Reproduction and Fertility 84 437-446.

Gerdes D, Wehling M, Leube B \& Falkenstein E 1998 Cloning and tissue expression of two putative steroid membrane receptors. Biological Chemistry 379 907-911.

Goff AK \& Smith LC 1998 Effect of steroid treatment of endometrial cells on blastocyst development during co-culture. Theriogenology $\mathbf{4 9}$ 1021-1030.

Green MP, Hunter MG \& Mann GE 2005 Relationships between maternal hormone secretion and embryo development on day 5 of pregnancy in dairy cows. Animal Reproduction Science 88 179-189. 
Hou Q \& Gorski J 1993 Estrogen receptor and progesterone receptor genes are expressed differentially in mouse embryos during preimplantation development. PNAS 90 9460-9464.

Inskeep EK 2004 Preovulatory, postovulatory, and postmaternal recognition effects of concentrations of progesterone on embryonic survival in the cow. Journal of Animal Science 82 E24-E39.

Lamming GE \& Royal MD 1999 Ovarian hormone patterns and subfertility in dairy cows. Proceedings of an International Symposium Organized by the British Society of Animal Science Entitled 'Fertility in the HighYielding Dairy Cow', Galway, Ireland, September 1999. BSAS, Occasional Publication 2001. 26 105-118.

Lessey BA, Alexander PS \& Horwitz KB 1983 The subunit structure of human breast cancer progesterone receptors: characterization by chromatography and photoaffinity labeling. Endocrinology 112 1267-1274.

Lonergan P, Woods A, Fair T, Carter F, Rizos D, Ward F, Quinn K \& Evans A 2007 Effect of embryo source and recipient progesterone environment on embryo development in cattle. Reproduction, Fertility, and Development 19 861-868.

Mann GE \& Lamming GE 2001 Relationship between maternal endocrine environment, early embryo development and inhibition of the luteolytic mechanism in cows. Reproduction 121 175-180.

McNeill RE, Diskin MG, Sreenan JM \& Morris DG 2006 Associations between milk progesterone concentration on different days and with embryo survival during the early luteal phase in dairy cows. Theriogenology 65 1435-1441.

Merlo B, lacono E \& Mari G 2007 Effect of progesterone and epidermal growth factor on in vitro-produced eight-cell bovine embryos in a serumfree culture medium. Reproduction, Fertility, and Development 19211.

Meyer C, Schmid R, Scriba PC \& Wehling M 1996 Purification and partial sequencing of high-affinity progesterone-binding site(s) from porcine liver membranes. European Journal of Biochemistry 239 726-731.

Milgrom E, Atger M \& Baulieu EE 1970 Progesterone in uterus and plasma. IV. Progesterone receptor(s) in guinea pig uterus cytosol. Steroids $\mathbf{1 6}$ 741-754.

Peluso J, Pappalardo A, Losel R \& Wehling M 2006 Progesterone membrane receptor component 1 expression in the immature rat ovary and its role in mediating progesterone's antiapoptotic action. Endocrinology 147 3133-3140.

Pereira RM, Marques CC, Baptista MC, Vasques MI \& Horta AE 2009 Embryos and culture cells: a model for studying the effect of progesterone. Animal Reproduction Science 111 31-40.

Rambags BP, van Rossem AW, Blok EE, de Graaf-Roelfsema E, Kindahl H, van der Kolk JH \& Stout TA 2008 Effects of exogenous insulin on luteolysis and reproductive cyclicity in the mare. Reproduction in Domestic Animals 43 422-428.
Rao BR, Wiest WG \& Allen WM 1974 Progesterone "receptor" in human endometrium. Endocrinology 95 1275-1281.

Reggio BC, Lynn JW \& Godke RA 1997 The effect of progesterone on the development of IVF-derived bovine embryos cultured in a semi-defined culture medium. Theriogenology 47284.

Rings F, Carter F, Holker M, Kuzmany A, Besenfelder U, Havlicek V, Tesfaye D, Schellander K \& Lonergan P 2008 Effect of elevated circulating progesterone concentration on development of in vitro produced bovine zygotes in vivo. Reproduction, Fertility, and Development 20 147-148.

Rizos D, Ward F, Duffy P, Boland MP \& Lonergan P 2002 Consequences of bovine oocyte maturation, fertilization or early embryo development in vitro versus in vivo: implications for blastocyst yield and blastocyst quality. Molecular Reproduction and Development $61234-248$.

Rizos D, Pintado B, de la Fuente J, Lonergan P \& Gutierrez-Adan A 2007 Development and pattern of mRNA relative abundance of bovine embryos cultured in the isolated mouse oviduct in organ culture. Molecular Reproduction and Development 74 716-723.

Satterfield MC, Bazer FW \& Spencer TE 2006 Progesterone regulation of preimplantation conceptus growth and galectin 15 (LGALS15) in the ovine uterus. Biology of Reproduction 75 289-296.

Shimada M, Kawano N \& Terada T 2002 Delay of nuclear maturation and reduction in developmental competence of pig oocytes after mineral oil overlay of in vitro maturation media. Reproduction 124 557-564.

Stronge AJ, Sreenan JM, Diskin MG, Mee JF, Kenny DA \& Morris DG 2005 Post-insemination milk progesterone concentration and embryo survival in dairy cows. Theriogenology 64 1212-1224.

Thouas GA, Korfiatis NA, French AJ, Jones GM \& Trounson AO 2001 Simplified technique for differential staining of inner cell mass and trophectoderm cells of mouse and bovine blastocysts. Reproductive Biomedicine Online 3 25-29.

Ying C, Yang YC, Hong WF, Cheng WT \& Hsu WL 2000 Progesterone receptor gene expression in preimplantation pig embryos. European Journal of Endocrinology 143 697-703.

Zheng P, Si W, Bavister BD, Yang J, Ding C \& Ji W 2003 17Beta-estradiol and progesterone improve in-vitro cytoplasmic maturation of oocytes from unstimulated prepubertal and adult rhesus monkeys. Human Reproduction 18 2137-2144.

Received 21 April 2009

First decision 20 May 2009

Accepted 25 June 2009 